\title{
MODEL MEKANISME ADMINISTRATIF TERINTEGRASIPADA IMPLEMENTASI STRATEGI DI LEVEL UNIT BISNIS STRATEGIS
}

\author{
Dwi Sulistiani \\ Email : tiaraakbar2006@yahoo.com
}

\begin{abstract}
Abstrak: Tulisan ini menindaklanjuti pandangan terpadu tentang elemen penting dari tiga mekanisme administratif: struktur organisasi, sistem kontrol dan manajer yang berkaitan dengan perbedaan dalam strategi kompetitif SBU (strategic business unit).Tulisan ini berdasarkan penelitian Govindarajan (1988) yang mencoba menemukan model untuk implementasi beragam strategi SBU yang dijalankan oleh korporasi berbeda. Hasilnya ditemukan bahwa lokus kontrol internal manajerial yang tinggi dan emphasis yang rendah pada pemenuhan sebuah budget berhubungan dengan kinerja tinggi dalam SBU yang menjalankan strategi diferensiasi. Hasil berbasis analisis sistem menunjukkan bahwa ketika gaya evaluatif budget, desentralisasi dan lokus kontrol berhubungan untuk memenuhi kebutuhan strategi SBU, maka dihasilkan kinerja superior. Kesesuaian sistem ini adalah sangat kuat antar SBU diferensiasi, tapi tidak begitu kuat antar unit low cost.
\end{abstract}

Kata Kunci: implementasi strategi, gaya evaluatif budget, lokus kontrol, dan desentralisasi.

\section{PENDAHULUAN}

Beberapa perusahaan menghadapi kesulitan dalam mengendalikan operasi divisinya ketika keragaman, ukuran, dan jumlah dari unit-unit ini terus meningkat.Manajemen korporat mungkin menghadapi kesulitan dalam mengevaluasi dan mengendalikan divisi-divisinya yang banyak dan seringkali bersifat multiindustri.Dalam kondisiini oleh Pearce dan Robinson (2007: 429) disarankan untuk menambahkan satu lapisan manajemen lagi guna meningkatkan implementasi, mendorong sinergi, dan memperoleh kendali lebih besar terhadap kepentingan-kepentingan bisnis yang beragam.

Literatur manajemen strategis membagi segmen korporasi menjadi beberapa unit bisnis strategis (Pearce dan Robinson, 2007; Hitt, et al., 2005).Unit bisnisstrategis (strategic business unit-SBU) adalah adaptasi struktur-struktur divisi di mana berbagai divisi atau bagian dari divisi di kelompokkan berdasarkan elemen-elemen strategis yang dimiliki bersama, biasanya dikaitkan dengan perbedaan dalam produk/pasar tertentu (Pearce dan Robinson, 2007: 429). Setiap SBU menjalankan strategi berbeda. Implikasi dari praktek tersebut membuat chief executive dari perusahaan yang terdiversifikasi harus menjalankan beberapa strategidalam perusahaan yang sama.

Dwi Sulistiani, adalah Dosen Prodi Akuntansi UIN MALIKI Malang 
Sebagian besar studi penelitian sebelumnya tentang manajemen perusahaan yang terdiversifikasi hanya menindaklanjuti subyek formulasi kebijakan dan bukan perihali mplementasi.Pertimbangan ini hanya berkaitan dengan bagaimana pilihan strategi yang tepat bisa dijalankan di beragam bisnis (Porter, 1985, 2004). Hal berbeda dalam penelitian Govindarajan (1988) mencoba menemukan model untuk implementasi beragam strategi SBU yang dijalankan oleh korporasi berbeda.

Model implementasi strategi yang digunakan Govindarajan (1988) dibuat berdasarkan beberapa hal berikut: (1) strategi yang dipilih oleh sebuah organisasi akan menentukan kadar ketidakpastian yang harus diatasi oleh organisasi; (2) mekanisme administratif berbeda bisa dijalankan untuk membantu organisasi mengatasi ketidakpastian; (3) Karena itu, penyesuaian mekanisme administratif dengan strategi cenderung berhubungan dengan kinerja yang superior.

Ini menunjukkan bahwa tindaklanjut terhadap ketidakpastian adalah masalah dasar dalam strategi implementasi yang efektif (March dan Simon, 1958; Thompson, 1967 dalam Govindarajan, 1988). Studi sebelumnya menemukan tiga mekanisme administratif yang digunakan perusahaan untuk menindaklanjuti ketidakpastian: desain struktur organisasi (Tushmandan Nadler, 1978), desain sistemkontrol (Hayes, 1977), dan seleksi manajer (Gupta dan Govindarajan, 1984). Literatur tentang sistem kontrol mengemukakan pandangan bahwa karena tugas beragam dalam ketidakpastiannya, perilaku yang dibutuhkan untuk kinerja efektif juga beragam; karena sistem kontrol berbeda menyebabkan perilaku yang berbeda, kinerja superior bisa dicapai dengan menyesuaikan sistem kontrol dengan ketidakpastian tugas (Govindarajan, 1984). Studi tentang manajer menemukan bahwa karakteristik manajerial berbeda secara sistematik berhubungan dengan kebutuhan organisasi untuk menindaklanjuti ketidakpastian (Gupta dan Govindarajan, 1984).

Karena itu, strategi penyesuaian dengan struktur organisasi, sistem kontrol, dan karakteristik manajer diharapkan bisa berhubungan dengan kinerja superior. Tulisan ini menindaklanjuti pandangan terpadu tentang elemen penting dari tiga mekanisme administratif: struktur organisasi, sistem kontrol dan manajer yang berkaitan dengan perbedaan dalam strategi kompetitif SBU.

\section{TINJAUAN PUSTAKA \\ IMPLEMENTASI STRATEGI}

Penjelasan mengenai implementasi ini berpijak dari tahapan-tahapan manajemen strategi.Strategi manajemen dirancang untuk menjadi pegangan bagaimana seharusnya bisnis perusahaan dijalankan dan bagaimana pengambilan keputusan diambil diantara berbagai alternatif pilihan tindakan yang tersedia. Strategi didasarkan pada misi yang telah ditetapkan untuk menuju visi yang diinginkan. Tanpa visi dan misi manajemen tidak punya tuntutan untuk diikuti, tidak punya peta untuk dijalani, tidak punya program yang dapat dijalankan, dan tidak ada langkah terencana dalam bentuk budget yang dapat diikuti, yang ada adalah tindakan-tindakan dadakan yang tidak terencana, sekedar reaksi terhadap berbagai perkembangan yang terjadi. Hasilnya tentu banyak gagal daripada berhasil. 
Pearce dan Robinson (2007) mendefinisikan manajemen strategis (Strategic Management) sebagai satu set keputuan dan tindakan yang menghasilkan formulasi dan implementasi rencana yang dirancang untuk meraih tujuan suatu perusahaan. Manajemen strategi terdiri atas sembilan tugas penting:

1. Merumuskan misi perusahaan termasuk pernyataan yang luas mengenai maksud, filosofi, dan sasaran perusahaan.

2. Melakukan suatu analisis yang mencerminkan kondisi dan kapabilitas internal perusahaan.

3. Menilai lingkungan eksternal perusahaan, termasuk faktor persaingan dan faktor kontekstual umum lainnya.

4. Menganalisis pilihan-pilihan dimiliki oleh perusahaan dengan cara menyesuaikan sumber dayanya dengan lingkungan eksternal.

5. Mengidentifikasikan pilihan paling menguntungkan dengan cara mengevaluasi setiap pilihan berdasarkan misi perusahaan.

6. Memilih satu set tujuan jangka panjang dan strategi utama yang akan menghasilkan pilihan paling menguntungkan tersebut.

7. Mengembangkan tujuan tahunan dan strategi jangka pendek yang sesuai dengan tujuan jangka panjang dan strategi utama yang telah ditentukan.

8. Mengimplementasikan strategi yang telah dipilih melalui alokasi sumber daya yang dianggarkan dimana penyesuaian antara tugas kerja, manusia, struktur, teknologi, dan sistem penghargaan ditekankan.

9. Mengevaluasi keberhasilan proses strategi sebagai masukan pengambilan keputusan di masa mendatang.

Model manajemen strategi yang dikembangkan oleh Hunger dan Wheelen (Indrajit dan Djokopranoto, 2006:64) membagi proses manajemen strategis menjadi empat langkah atau empat elemen dasar, yaitu: (1)pemindaian lingkungan, terdiri dari: analisis eksternal dan analisis internal. (2)Formulasi strategi, terdiri dari: penentuan misi, penentuan obyektif, pembuatan strategi dan pementuan kebijakan. (3)Implementasi strategi, terdiri dari: pembuatan program, penyusunan anggaran dan pembuatan prosedur. (4)Evaluasi dan pengawasan, terdiri dari: pengukuran kinerja.

Diskusi mengenai implementasi strategi merupakan bagian dari tahapan strategi manajemen. Menelusuri lebih jauh penjelasan mengenai implementasi berdasarkan definisi Pearce dan Robinson (2007) dan Hunger dan Wheelen (Indrajit dan Djokopranoto, 2006:64). Terdapat benang merah bahwa implementasi strategi tidak lepas dari tiga mekanisme administratif seperti yang menjadi bahasan pada tulisan ini yaitu: gaya evaluatif budget, lokus kontrol, dan desentralisasi.

\section{PEMBAHASAN}

\section{Karakteristik Strategi Kompetitif Dan Mekanisme Administratif} Strategi Kompetitif

Tulisan ini menggunakan kerangka strategi Porter (2004), karena konseptualisasi secara akademis diterima dan konsisten internal. Porter (2004) mengemukakan dua cara yang digunakan SBU untuk mendapatkan keuntungan 
kompetitif di atas perusahaan dalam industri: "low cost" dan "diferensiasi”. Sebuah strategi low-cost menitikberatkan pada kebutuhan untuk menghasilkan biaya terendah di dalam sebuah industri; Commodore menjalankan strategi ini dalam mesin bisnis. Strategi ini membutuhkan "konstruksi fasilitas skala-yang efisien dan agresif, pencapaian reduksi biaya dari pengalaman, kontrol biaya dan overhead yang ketat, penghindaran akun konsumen marjinal dan minimisasi biaya dalam area seperti R\&D, jasa, tenaga sales, advertising, dst" (Porter, 2004). Dalam sebuah strategi diferensiasi, sebuah perusahaan bisa dijalankan dalam industri sepanjang dimensi yang dinilai tinggi oleh pembeli; Mercedes menggunakan strategi ini dalam bisnis automobil. Dalam strategi ini, seuah perusahaan "memilih satu atau beberapa atribut yang dianggap banyak pembeli dalam sebuah industri sebagai yang penting, dan posisi itu sendiri memenuhi kebutuhan tersebut. Ini berhubungan dengan keunikan dari harga premium" (Porter, 2004).

Fakta bahwa SBU menjalankan strategi low-cost bukan berarti bahwa ini mengabaikan kualitas, jasa, fitur, atau basis lain untuk diferensiasi. Sebuah SBU yang menjalankan strategi differensiasi tidak dapat mengabaikan biaya. Untuk mengutip Porter: "Sebuah strategi diferensiasi tidak membuat perusahaan mengabaikan biaya, tapi bukan target strategi yang primer" (2004) dan "Sebuah strategi low-cost menunjukkan bahwa low cost dibanding pesaing menjadi tema pokok di sepanjang strategi keseluruhan, meski kualitas, jasa dan area lain tidak dapat diabaikan" (2004). Karena itu, menurut Porter, kita perlu mengukur strategi kompetitif untuk menghasilkan tradeoffSBU antara menjadi leader biaya dan pencapaian diferensiasi.

\section{Gaya Evaluatif Budget}

Fokus gaya evaluatif budget adalah relevan, menurut tempat sentral dari sistem evaluasi kinerja di dalam literatur akuntansi dan kontrol (Govindarajan, 1984). Kinerja manajer umum SBU dapat dievaluasi berbasis beberapa tipe data, baik kuantitatif dan kualitatif. Studi ini menfokuskan pada peran yang dimainkan oleh salah satu tipe data - budget profit. Sebuah budget profit merepresentasikan tujuan profit tahunan (pendapatan sales dikurangi beban) sebuah SBU yang diekspresikan dalam ukuran moneter.

Menurut Otley (1978) dalam Govindarajan (1984), gaya evaluatif budget sebagai variabel kontinyu membuat nilainya ditentukan lewat jumlah emphasis yang menerima tujuan budget selama proses evaluasi kinerja sebuah manajer umum SBU. Pada satu akhir spektrum terdapat situasi yang mana informasi budget memainkan peran yang tidak penting dalam evaluasi superior kinerja manajer umum SBU. Di sisi lain adalah situasi dimana kemampuan untuk memenuhi budget secara kontinyu dan dimana manajer menerima evaluasi kinerja yang tidak menyenangkan, jika ada variansi budget yang tidak disukai, meski berkadar kecil.

\section{Desentralisasi}

Desentralisasi sebagai mekanisme struktural penting untuk mendukung implementasi strategi efektif (Vancil, 1980 dalam Govindarajan, 1986). Desentralisasi dianggap sebagai jumlah otoritas pembuatan keputusan yang didelegasikan ke sebuah manajer umum SBU oleh superior korporat. Desentralisasi 
antara sebuah kantor korporat dan manajer umum perlu dipertimbangkan, tapi desentralisasi dalam SBU tidak dijalankan.

\section{Lokus kontrol}

Hubungan antara lokus kontrol manajer umum dan strategi ini memberikan banyak kemudahan untuk menjelaskan kinerja organisasi (Miller dan Toulouse, 1986 dalam Govindarajan, 1984). Konsep mendasar ini, bahwa kontrol penguatan internal versus eksternal, berkembang dari teori pembelajaran sosial. Kontrol internal merupakan kejadian yang dirasakan individu, baik positif atau negatif, sebagai akibat tindakannya sendiri dan karena itu, berada dalam kontrol personal. Kontrol eksternal ini dianggap menganggap kejadian positif dan negatif sebagai yang tidak terkait dengan perilaku personal dan karena itu di luar kontrol personal.

\section{Mekanisme Administratif Terintegrasi Dalam Unit Bisnis Strategis Strategi Administratif Terhadap Ketidakpastian}

Pilihan sebuah strategi differensiasi selain strategi low-cost akan meningkatkan ketidakpastian dalam lingkungan tugas SBU (Govindarajan, 1988). Pertama, inovasi produk cenderung lebih penting untuk SBU untuk menjalankan sebuah strategi differensiasi daripada yang menjalankan strategi low-cost (Porter, 2004).

Kedua, SBU yang menggunakan strategi low-cost cenderung punya lini produk sempit untuk meminimalkan biaya pengangkutan inventaris atau untuk merasakan keuntungan dari ekonomi skala (Porter, 2004). Di lain pihak, SBU yang menggunakan differensiasi cenderung punya set produk yang luas untuk menciptakan keunikan (Gupta, 1987). Luasnya produk berhubungan dengan kompleksitas lingkungan yang tinggi, dan juga, dengan ketidakpastian lingkungan (Gupta, 1987).

\section{Gaya Evaluatif Budget}

Semakin besar ketidakpastian, semakin sulit superior untuk menganggap target budget dari subordinat sebagai komitmen perusahaan dan menganggap variansi budget yang tidak diinginkan sebagai indikator jelas dari kinerja yang buruk (Govindarajan, 1984). Ada beberapa alasan: (1) Untuk mendapatkan target budget apriori yang dapat menjadi standar valid untuk penilaian kinerja, seorang individu harus mampu memprediksi kondisi yang ada selama tahun mendatang. Ada kemungkinan untuk memprediksi kondisi tersebut secara akurat dalam kondisi lingkungan yang stabil daripada dalam kondsi lingkungan yang tidak pasti. Karena itu, dengan ketidakpastian yang tinggi, manajer cenderung termotivasi dan beraksi dalam cara disfungsional ketika menghadapi tujuan budgetnya; (2) Efisiensi adalah jumlah input per unit output. Evaluasi efisiensi manajerial yang menggunakan sebuah budget, karena itu, ditentukan oleh pengetahuan hasil detail terkait tindakan manajerial, atau, dengan kata lain, pengetahuan tentang hubungan sebab-akibat.

Thompson (1967) dalam Govindarajan (1988) berpendapat bahwa pengetahuan lengkap tentang hubungan sebab-akibat bisa muncul dalam kondisi stabil dan pengetahuan yang tidak lengkap bisa muncul dalam kondisi yang tidak pasti; (3) Emphasis sebuah budget adalah pada hasil bukan proses. Manajer punya kontrol terhadap tindakannya tapi tidak pada kondisi yang bisa menggabungkan 
tindakannya untuk mencapai hasil. Dalam sebuah situasi dengan ketidakpastian yang tinggi, informasi budget saja tidak cukup mencerminkan kinerja manajerial.

Keterkaitan antara gaya evaluatif budget dan ketidakpastian, dalam konteks hubungan antara ketidakpastian dan strategi kompetitif, menghasilkan dugaan sebagai berikut bahwa SBU yang menggunakan sebuah strategi diferensiasi, pengurangan perhatian pada tujuan budget selama evaluasi kinerja berhubungan dengan efektivitas SBU yang tinggi. SBU yang menggunakan strategi low cost, perhatian kepada tujuan budget selama evaluasi kinerja cenderung berhubungan dengan efektivitas SBU yang tinggi.

Argumen berikut, meski tidak terkait dengan ketidakpastian, juga mendukung dugaan bahwa SBU yang menggunakan sebuah strategi diferensiasi, pengurangan perhatian pada tujuan budget selama evaluasi kinerja berhubungan dengan efektivitas SBU yang tinggi. SBU yang menggunakan strategi low cost, perhatian kepada tujuan budget selama evaluasi kinerja cenderung berhubungan dengan efektivitas SBU yang tinggi: (1) Sebagian besar faktor yang membuat SBU menjalankan strategi differensiasi secara sukses tidak bisa diukur dari sebuah budget saja. Faktor tersebut sulit dihitung dalam cara apapun karena keuntunganya sulit dihitung, tapi seringkali sulit diidentifikasi. Contoh, banyak SBU yang menjalankan diferensiasi merasakan sukses karena dikenal bisa menghasilkan produk kualitas tertinggi. Biaya yang dibutuhkan untuk mencapai level kualitas tersebut perlu ditentukan. Meski begitu, keuntungan yang dirasakan sebuah SBU karena reputasinya sulit diukur, kecuali bahwa tanpa imej kualitas ini, SBU kemungkinan tidak mendapat posisi dalam profitabilitas dan pertumbuhan. Imej brand dan deliveri yang cepat juga masuk dalam kategori ini; (2) Jumlah yang dikeluarkan untuk faktor diferensiasi (advertising, kualitas tinggi, deliveri cepat, produk $\mathrm{R} \& \mathrm{D}$, dst) dikategorikan sebagai pengeluaran diskresioner, dan biasanya korban pertama dari ukuran pemotongan-biaya. Untuk menyesuaikan manajer SBU dengan tujuan budget adalah menempatkan faktor tersebut pada resiko (Hayes dan Abernathy, 1980; Richardson dan Gordon, 1980); (3) SBU low-cost ini umumnya punya marjin rendah daripada SBU diferensiasi dan membuat profitnya dari volume, bukan dari marjin profit yang tinggi. Kondisi ini berarti bahwa produsen low cost punya sedikit ruang untuk error. Manajer SBU tersebut karena itu terdorong untuk memenuhi budgetnya.

\section{Desentralisasi}

Desentralisasi yang tinggi adalah sebuah respon tepat kepada peningkatan ketidakpastian (Govindarajan, 1986). Lingkungan tugas menjadi lebih tidak pasti, dan dibutuhkan lebih banyak informasi. Sentralisasi bisa memungkinkan pada level ketidakpastian yang rendah karena informasi yang diproses tidak membebani hirarki organisasi. Meski begitu, ketika ketidakpastian meningkat, semakin banyak harapan yang naik dalam hirarki. Ketika banyak harapan yang dirujuk ke atas, hirarki bisa overload. Delay serius terbentuk antara transmisi ke atas untuk informasi tentang situasi baru dan respon terhadap informasi tersebut ke bawah. Cara efektif untuk menindaklanjuti situasi tersebut adalah menggerakkan level pembuatan keputusan ke tempat dimana informasi berada, bukannya membawa ke atas dalam hirarki, yang semakin menunjukkan bahwa desentralisasi dalam pembuatan keputusan sebagai respon terhadap peningkatan ketidakpastian. Karena 
itu, tulisan ini memunculkan dugaan bahwaSBU yang menggunakan strategi diferensiasi, kenaikan dalam desentralisasi cenderung berhubungan dengan efektivitas $S B U$ yang tinggi. Untuk $S B U$ yang menggunakan strategi low cost, kenaikan dalam desentralisasi cenderung berhubungan dengan efektivitas $S B U$ yang tinggi.

Argumen berikut, tidak berakar dalam ketidakpastian, memberikan dukungan tambahan untuk dugaan dugaan bahwa $S B U$ yang menggunakan strategi diferensiasi, kenaikan dalam desentralisasi cenderung berhubungan dengan efektivitas $S B U$ yang tinggi. Untuk $S B U$ yang menggunakan strategi low cost, kenaikan dalam desentralisasi cenderung berhubungan dengan efektivitas $S B U$ yang tinggi. Gupta dan Govindarajan (1986) menemukan bahwa interdependensi dengan unit bisnis lain terkesan lebih menguntungkan untuk $S B U$ low cost daripada $S B U$ diferensiasi, karena pembagian aktivitas ini membantu meminimalkan biaya keseluruhan, yang lebih bisa dirasakan dalam unit low cost.

\section{Lokus Kontrol}

Hasil dari dua kelompok studi menghasilkan kesimpulan bahwa orang dengan lokus kontrol internal bisa berkinerja lebih baik daripada orang dengan lokus kontrol eksternal dalam kondisi ketidakpastian yang tinggi. Kelompok studi pertama menunjukkan kemampuan individu untuk mendapatkan dan menggunakan informasi. Secara khusus, studi tersebut menemukan bahwa (1) orang dengan lokus internal mencari informasi relevan-tugas secara lebih aktif daripada orang dengan lokus eksternal (Organ dan Greene, 1974) dan (2) kelompok pertama terkesan lebih efisien dalam penggunaan informasi daripada yang kedua (Spector, 1982). Logika di balik kemampuan pengolahan informasi yang lebih besar di pihak dengn lokus internal sepertinya didasarkan pada gagasan dimensi internal-eksternal. Orang dengan lokus internal, yang punya harapan tinggi bahwa reward adalah fungsi dari usahanya, akan mencari informasi terkait-tugas secara aktif dan menggunakan informasi tersebut, karena mereka cenderung melihat akuisisi dan utilisasi informasi relevan sebagai sebuah jalur menuju pemberdayaan. Orang dengan lokus eksternal, di lain pihak, yang memiliki harapan bahwa usahanya bukanlah hal penting untuk pencapaian reward, tidak akan secara aktif mencari dan menggunakan informasi. Galbraith (1973) dalam Govindarajan (1984) berpendapat bahwa semakin besar ketidakpastian, semakin besar jumlah informasi yang diproses. Karena itu, individu denga lokus internal diperkirakan akan menghadapi ketidakpastian secara lebih efektif daripada pihak dengan lokus eksternal.

Kelompok studi kedua (Anderson, Hellriegel, dan Slocum, 1977; Gore dan Rotter, 1963; Mitchell, Smyser, dan Weed, 1975) menindaklanjuti hubungan antara ketidakpastian dan lokus kontrol secara langsung dengan memberikan bukti bahwa pihak dengan lokus kontrol internal akan beradaptasi dengan perubahan lingkungan secara lebih baik daripada pihak dengan lokus eksternal. Karena itu, dugaan berikutnya bahwa $S B U$ yang menggunakan strategi diferensiasi, lokus kontrol internal yang besar di pihak manajer umum $S B U$ cenderung berhubungan dengan efektivitas $S B U$ yang tinggi. $S B U$ yang menggunakan strategi low cost, lokus kontrol eksternal yang lebih besar di pihak manajer umum $S B U$ cenderung berhubungan dengan efektivitas $S B U$ yang tinggi. 


\section{Kesesuaian Sistem}

Berdasarkan tiga dugaan sebelumnya bahwa masing-masing menfokuskan pada hubungan antara strategi kompetitif dan satu mekanisme administratif spesifik dan efek interaktifnya terahadap kinerja. Secara keseluruhan diperlukan dugaan berikutnya untuk keterkaitan antara mekanisme administratif dan strategi.

Menurut argumen teoritis yang mendukung dugaan-dugaan sebelumnya menunjukkan bahwa jika $S B U$ menindaklanjuti semua tiga mekanisme administratif secara simultan terhadap strategi, ini bisa dijalankan pada level efektivitas yang tinggi daripada yang diperkirakan. Dugaan berikutnya kesesuaian sistem bahwa kesesuaian yang tepat dari tiga mekanisme administratif (gaya evaluatif budget, desentralisasi dan lokus kontrol) dengan strategi berhubungan dengan efektivitas $S B U$ yang tinggi. Ketidaksesuaian berhubungan dengan efektivitas yang rendah.

\section{Kajian Bukti Empiris}

Kajian bukti empiris pada tulisan ini di dasarkan pada studi oleh Govindarajan (1988) dapat dijelaskan seperti berikut: lokus kontrol internal manajerial yang tinggi dan emphasis yang rendah pada pemenuhan sebuah budget berhubungan dengan kinerja tinggi dalam $S B U$ yang menjalankan strategi diferensiasi. Penemuan hasil ini setelah mengontrol efek $S B U$ dan ukuran korporat terhadap kinerja. Dapat disimpulkan bahwa tidak memberikan dukungan bagi interaksi antara strategi $S B U$, desentralisasi, dan efektivitas.

Hasil berbasis analisis sistem menunjukkan bahwa ketika gaya evaluatif budget, desentralisasi dan lokus kontrol berhubungan dengan tepat untuk memenuhi kebutuhan strategi $S B U$, maka dihasilkan kinerja superior. Kesesuaian sistem ini adalah sangat kuat antar $S B U$ diferensiasi, tapi tidak begitu kuat antar unit low cost.

Berdasarkan hasil di atas secara keseluruhan sistem menghasilkan beberapa wawasan berguna yang tidak dapat diperoleh jika hanya pada satu pendekatan. Pertama, hasil sistem menunjukkan bahwa semua mekanisme administratif adalah penting dalam implementasi strategi. Kedua, kesesuaian hanya untuk dua mekansime administratif, yang karena itu berarti bahwa gaya evaluatif budget dan lokus kontrol adalah prediktor yang lebih menonjol untuk kinerja daripada desentralisasi. Karena itu, para eksekutif korporat menfokuskan, pertama kali, pada penyesuaian gaya evaluatif budget dan lokus kontrol terhadap strategi.

Hasil terkait lokus kontrol memberikan ekstensi yang berguna dengan menghubungkan kesesuaian antara lokus kontrol dan strategi bisnis dengan kinerja. Meski menurut Vancil (1980) dalam Govindarajan (1984) berusaha menjelaskan perbedaan dalam level desentralisasi rata-rata antar perusahaan menurut perbedaan dalam strategi korporat perusahaan, hasil sistem bisa menjelaskan mengapa level desentralisasi menjadi beragam antar $S B U$ dalam beberapa perusahaan.

Studi Govindarajan (1988) ini punya relevansi praktis dan teoritis. Pada level praktek, ini menjadi acuan bagi chief executive officer dari organisasi multi bisnis bahwa mereka tidak seharusnya menggunakan pendekatan standar dan seragam untuk mengelola bisnisnya; tapi, ini menggunakan sebuah pendekatan fleksibel, yang menyusun pendekatan kepada strategi unit bisnis. Secara khusus, studinya 
mempunyai aplikasi praktikal dalam dua area penting: manajemen sumberdaya manusia strategis dan desain sistem-kontrol.

Dari sudut pandang manajemen sumberdaya manusia srategis, studinya punya implikasi bukan hanya bagi pihak yang bertanggungjawab pada seleksi dan pengembangan manajer umum dalam perusahaan diversifikasi, tapi juga bagi manajer umum itu sendiri. Bagi seorang atasan, manajer umum yang dipilih untuk jabatan tersebut haruslah salahsatu yang lokus kontrolnya adalah tepat untuk strategi $S B U$ yang dijalankan. Dalam cara tersebut, manajer umum, yang membahas tugas kerja masa depan, harus memilih $S B U$ dengan sebuah strategi yang menyesuaikan dimensi lokus kontrolnya. Setiap keputusan tersebut harus mempertimbangkan tujuan tersebut - untuk meningkatkan level keseluruhan dari efektivitas $S B U$.

Studi Govindarajan (1988) ini dapat membantu praktisioner untuk menghasilkan pendekatan baru untuk desain sistem kontrol. Hayes dan Abernathy, (1980) mengatakan bahwa sistem kontrol finansial yang digunakan oleh korporasi US, yang menitikberatkan ukuran profit jangka pendek dalam budget profit, bisa menyebabkan kurangnya persaingan internasional di pihak perusahaan US. Salah satu implikasinya adalah bahwa kontrol finansial seperti sistem evaluasi berbasis budget perlu dilunakkan jika eksekutif Amerika ingin inovatif dan menjaga persaingan globalnya. Studinya menunjukkan bahwa korporasi US tidak boleh terlalu dikontrol tapi salah kontrol. Contoh, memenuhi sebuah budget bisa menjadi sebuah tujuan yang tepat untuk $S B U$ low cost, tapi teknik yang lebih fleksibel bisa dijalankan untuk mengelola $S B U$ berbeda.

Dari perspektif pengembangan teori, studi Govindarajan (1988) ini menambahkan aliran penelitian tentang manajemen strategis yang menjelaskan persoalan implementasi strategi di level unit bisnis. Tulisan ini mempelajari keterkaitan antara strategi $S B U$ dan tiga mekanisme administratif (struktur organisasi, sistem kontrol, dan lokus kontrol manajer), khususnya ketika ini berhubungan dengan efektivitas unit bisnis.

\section{KESIMPULAN}

Tulisan ini menfokuskan pada apa yang dianggap sebagai aspek penting dari implementasi strategi dalam organisasi multi bisnis bahwa unit bisnis berbeda dalam korporasi yang sama sering menjalankan strategi berbeda dan bahwa mekanisme administratif yang digunakan kantor pusat korporat untuk mengatur bisnisnya harus berbeda. Tulisan ini didasarkan dari studi yang dilakukan Govindarajan (1988) menemukan bahwa lokus kontrol internal manajerial yang tinggi dan emphasis yang rendah pada pemenuhan sebuah budget berhubungan dengan kinerja tinggi dalam SBU yang menjalankan strategi differensiasi.

Hasil berbasis analisis sistem menunjukkan bahwa ketika gaya evaluatif budget, desentralisasi dan lokus kontrol berhubungan dengan tepat untuk memenuhi kebutuhan strategi $S B U$, maka dihasilkan kinerja superior. Kesesuaian sistem ini adalah sangat kuat antar $S B U$ diferensiasi, tapi tidak begitu kuat antar unit low cost. 


\section{DAFTAR PUSTAKA}

Daft, Richard L. 1994. Management, 3rd Edition. The Dryden Press. Orlando.

Govindarajan, Vijay. 1984. Appropriateness os Accounting Data In Performance Evaluation: An Empirical Examination of Environmental Uncertainty As An Intervening Variable. Accounting, Organizations And Society.Vol 9. No.2;125-135.

Govindarajan, Vijay. 1986. Decentralization, Strategy, And Effectiveness of Strategic Business Unit in Multi-Business Organizations. Academy of Management Review. Vol 11: 844-856.

Govindarajan, Vijay. 1988. A Contingency Approach To Strategy Implementation At The Business-Unit Level: Integrating Administrative Mechanisms With Strategy. Academy of Management Journal.Vol 11. No.4;828-853.

Gupta, A.K. 1987. Matching Managers To Strategies: Point and Counterpoint. Human Resource Management. Vol. 25: 215-234.

Gupta, A.K.,\&Govindarajan, V. 1984. Business Unit Strategy, Managerial Characteristics and Business Unit Effectiveness at Strategy Implementation.Academy of Management Journal.Vol 27: 25-41.

Gupta, A.K.,\&Govindarajan, V. 1986. Resource Sharing Among SBUs: Strategic Antecedents and Administrative Implications. Academy of Management Journal.Vol 29: 695-71.

Hariadi, Bambang, 2003. Management Strategic.Bayumedia Publishing, Malang.

Hayes. 1977. The Contingency Theory Of Managerial Accounting. Accounting Review.Vol 2: 22-39.

Hayes \& Abernathy. 1980. Managing Our Way To Economic Decline. Harvard Business Review .Vol 58.No.4: 67-77.

Hitt, Michael A, R. Duane Ireland, and Robert E.Hoskisson, alihbahasa.2005. ManajemenStrategisDayasaing\&Globalisasi.BukuSatu. PenerbitSalemba. Jakarta.

http://www.angkasa_online.com/11/06/seabad/seabad.1htm.

Indrajit, Richardus.A, danDjokopranoto, Richardus. 2006. Manajemen Perguruan Tinggi Modern. Penerbit Andi. Yogyakarta.

Miler\& Toulouse. 1986. Chief Executive Personality and Corporate Strategy and Structure In Small Firms. Management Sciences. Vol. 32: 1389-1409. 
188 MODERNISASI, Volume 10, Nomor 3, Oktober 2014

Organ \& Greene. 1974. The Perceived Purposefullness of Job Behavior: Antecedent And Consequences. Academy of Management Journal. Vol. 17: 69-78.

Pearce, John A. Robinson JR, Richard B, alihbahasaYaniviBachtiardanChristines. 2007. ManajemenStrategik: Formulasi, Implementasi dan Pengendalian. Buku Satu. PenerbitSalembaEmpat. Jakarta.

Porter. 1985. Competitive Advantage:Creating and Sustaining Superior Performance. The Free Press: New York.

Porter, Michael E. 2004. Competitive Strategy. Free Press, New York.

Sugito, Hadi. 2005. Konsep Strategi Bisnis. Pusat Pengembangan Bisnis dan Manajemen (P2BM). Riau. 